\title{
CD10 and ICOS expression by multiparametric flow cytometry in angioimmunoblastic T-cell lymphoma
}

\author{
Lucile Baseggio ${ }^{1,4}$, Alexandra Traverse-Glehen ${ }^{2,4}$, Françoise Berger ${ }^{2,4}$, Martine Ffrench ${ }^{1,4}$, \\ Laurent Jallades $^{1,4}$, Dominique Morel ${ }^{1,4}$, Ghislaine Goedert ${ }^{1,4}$, Jean-Pierre Magaud ${ }^{1,4}$, \\ Gilles Salles ${ }^{3,4}$ and Pascale Felman ${ }^{1,4}$ \\ ${ }^{1}$ Laboratoire d'Hématologie Cellulaire, Centre Hospitalier Lyon-Sud, Pierre-Bénite, France; ${ }^{2}$ Service \\ d'Anatomie Pathologique, Centre Hospitalier Lyon-Sud, Pierre-Bénite, France; ${ }^{3}$ Service d'Hématologie, \\ Centre Hospitalier Lyon-Sud, Pierre-Bénite, France and ${ }^{4}$ UMR5239 CNRS/ENS Lyon/UCBL/HCL, Lyon, France
}

\begin{abstract}
Angioimmunoblastic T-cell lymphoma is immunologically defined by the expression of CD10 and the follicular helper $T$ cell $\left(T_{F H}\right)$ markers such as CXCL13, programmed death-1 (PD-1) and inducible T-cell costimulator (ICOS). This $\mathrm{T}_{\mathrm{FH}}$ profile has been mainly reported by immunohistochemistry. Here, using multiparametric flow cytometry, the relevance of ICOS and PD-1 to angioimmunoblastic T-cell lymphoma diagnosis was evaluated in lymph node $(n=15)$ as well as in peripheral blood $(n=13)$ among a series of 28 angioimmunoblastic T-cell lymphoma cases, in addition to the CD10 expression (available in 26 lymph node and 15 peripheral blood specimens). In this series, CD10 expression was present in $23 / 26(88 \%)$ lymph node and in $12 / 15(80 \%)$ peripheral blood cases and ICOS in $13 / 15(87 \%)$ lymph node and in $6 / 13(47 \%)$ peripheral blood cases, whereas neither significant CD10 nor ICOS T cells were identified in the control group (lymph nodes with reactive hyperplasia $=10$, peripheral blood of healthy donors $=15$ ). PD-1 expression was less informative as observed in both angioimmunoblastic T-cell lymphoma and control cases. The multiparametric approach allowed us to confirm the frequent blood dissemination in angioimmunoblastic T-cell lymphoma and to show that circulating neoplastic $T$ cells correspond more often to a CD10-positive subset than to an ICOS-positive subset. Consequently, if ICOS constitutes an additional feature for the diagnosis of angioimmunoblastic T-cell lymphoma, it appears less sensitive than CD10 expression for the detection of circulating neoplastic T cells. Modern Pathology (2011) 24, 993-1003; doi:10.1038/modpathol.2011.53; published online 15 April 2011
\end{abstract}

Keywords: angioimmunoblastic T-cell lymphoma; CD10; circulating neoplastic T cells; ICOS; multiparametric flow cytometry; PD-1

Angioimmunoblastic T-cell lymphoma is a rare entity accounting for $\sim 2 \%$ of all non-Hodgkin's lymphomas, but it represents one of the most frequent entities (15-20\%) among peripheral T-cell lymphoma ${ }^{1-3}$ and is characterized in most cases by an aggressive behavior. ${ }^{4}$ The diagnosis can be difficult based on morphological criteria alone, as the morphology can overlap with a variety of reactive and neoplastic disorders such as autoimmune diseases, reactive hyperplasia and sometimes

Correspondence: Dr P Felman, MD, Laboratoire d'Hématologie Cellulaire, Centre Hospitalier Lyon-Sud, 165 Chemin du Grand Revoyet, 69495 Pierre Benite Cedex, France.

E-mail: pascale.felman@chu-lyon.fr

Received 15 October 2010; revised 8 December 2010; accepted 8

December 2010; published online 15 April 2011 large B-cell lymphoma. Therefore, the definitive diagnosis requires additional immunologic and molecular data. The CD10 expression by neoplastic T cells observed in $80-90 \%$ of angioimmunoblastic T-cell lymphoma cases currently represents a specific diagnostic marker that has been demonstrated in several studies using immunohistochemistry as well as flow cytometry. ${ }^{4-9}$ The gene expression profiling analysis has demonstrated the cellular derivation of angioimmunoblastic T-cell lymphoma from follicular helper $\mathrm{T}$ cells $\left(\mathrm{T}_{\mathrm{FH}}\right.$ cells), ${ }^{10,11}$ that was initially suspected on the expression of $\mathrm{T}_{\mathrm{FH}}$ markers by immunohistochemistry, particularly the expression of the cytoplasmic CXCL13 chemokine. ${ }^{12,13}$ Then, additional $\mathrm{T}_{\mathrm{FH}}$ markers, including the cell surface molecules CXCR5, the programmed death-1 (PD-1), cytoplasmic SAP (SLAM-associated protein) 
and the transcription factor BCL6, have been reported as angioimmunoblastic T-cell lymphoma markers by immunohistochemistry. ${ }^{9,14-16}$ More recently, the inducible T-cell costimulator (ICOS) protein has been proposed to be suitable for identifying $\mathrm{T}_{\mathrm{FH}}$ cells and to be perhaps superior to PD-1 for angioimmunoblastic T-cell lymphoma diagnosis. ${ }^{17}$ Among T-cell lymphomas, ICOS expression analyzed by immunohistochemistry was indeed observed in angioimmunoblastic T-cell lymphoma (85/86 cases), and in the follicular variant of peripheral T-cell lymphoma, not otherwise specified (18/18 cases), a recently described variant of peripheral T-cell lymphoma showing phenotypic features in common with angioimmunoblastic T-cell lymphoma. ${ }^{16,17}$ ICOS was also expressed by some peripheral T-cell lymphomas, not otherwise specified, showing a $\mathrm{T}_{\mathrm{FH}}$-like profile $(24 / 56) .{ }^{17}$ Thus, ICOS appears rather as a diagnostic marker of $\mathrm{T}_{\mathrm{FH}}$-derived lymphomas that encompass angioimmunoblastic T-cell lymphomas and peripheral T-cell lymphomas, not otherwise specified, with some angioimmunoblastic T-cell lymphoma features. Interestingly, circulating ICOS-positive T cells were identified in two angioimmunoblastic T-cell lymphoma cases. ${ }^{17}$

The peripheral blood dissemination is a common feature in angioimmunoblastic T-cell lymphoma, ${ }^{7,18,19}$ and we and others demonstrated that the detection of circulating CD10-positive $\mathrm{T}$ cells by flow, whatever be the percentage of CD10-positive cells in lymph node and the lymphocyte count, is relevant for angioimmunoblastic T-cell lymphoma diagnosis. ${ }^{7,19}$ However, CD10 expression by T cells may be lacking or too faint to allow a firm diagnosis, which justifies the use of additional markers. CXCL13 and BCL6 represent useful and robust angioimmunoblastic T-cell lymphoma markers by immunohistochemistry, ${ }^{12,13}$ but they are not routinely available by flow cytometry in contrast to PD-1 and ICOS.

Here, we evaluate the relevance of the $\mathrm{T}_{\mathrm{FH}}$ markers ICOS and PD-1 to angioimmunoblastic T-cell lymphoma diagnosis in peripheral blood as well as in lymph node using multiparametric flow cytometry analysis, and in particular their usefulness for diagnosis improvement.

\section{Materials and methods}

\section{Samples}

A total of 28 angioimmunoblastic T-cell lymphoma cases were selected from the files of the hematology laboratory between 1996 and 2010. In all cases, angioimmunoblastic T-cell lymphoma diagnosis was histologically made by experienced hematopathologist (FB, ATG) on lymph node sections according to the WHO criteria. ${ }^{2}$ Among these 28 cases, 12 cases have been previously reported (Table 1, cases 1-12). ${ }^{7}$
In addition to the immunological markers routinely used in T-cell lymphoma diagnosis, the expression of ICOS and PD-1 was evaluated by flow cytometry in 15 lymph nodes and 13 peripheral blood samples. These cases have been cryoconserved in fetal calf serum (FCS; Vysis, Voisins le Bretonneux, France) with 10\% dimethyl sulfoxide (DMSO; Sigma, St Louis, MO, USA) in liquid nitrogen until use.

Lymph nodes with reactive hyperplasia $(n=10)$ and peripheral blood from healthy donors $(n=15)$ were used as control groups.

The immunohistochemistry staining has been previously described. ${ }^{7}$

\section{Flow Cytometry}

Fresh or thawed lymph node suspensions and peripheral blood samples were analyzed using an eight-color multiparametric staining in particular the $\mathrm{T}_{\mathrm{FH}}$ markers ICOS and PD-1. The eight antibodies used were as follows: CD57-FITC (clone NC1; Becton Dickinson, San Jose, CA, USA), ICOS-PE (CD278; clone ISA-3; eBioscience, Paris, France), CD279-PC7 (clone PD-1; Beckman-Coulter, Hialeah, FL, USA), CD10-APC (HI10a; Becton Dickinson), CD3-APC-Cy7 (clone SK7; Becton Dickinson), CD5-PercP-Cy5.5 (clone L17F12; Becton Dickinson), CD4-Pacific-blue (clone RPA-T4; Becton Dickinson) and CD8-AmCyan (clone SK1; Becton Dickinson). The other $\mathrm{T}$ and B-cell markers were realized at the time of diagnosis in all lymph node and peripheral blood cases. Methods for immunophenotype analysis by multiparametric flow cytometer have been previously reported. $^{7}$

The flow data were acquired on a BD FACSCanto II cytometer, which was daily calibrated with BD Cytometer Setup and Tracking Beads, and were analyzed with BD FACS DIVA software (all from Becton Dickinson). Fresh blood samples were lyzed using BD FACS (lyse/Wash assistant; Becton Dickinson). As previously defined, ${ }^{7}$ a CD10 expression by the CD4-positive or CD5-positive T cells $\geq 5 \%$ of CD4-positive or CD5-positive T cells was considered as positive. The ICOS and PD-1 expression by T cells was evaluated by different methods. As only a subset of $\mathrm{T}$ cells expressed ICOS, ${ }^{17}$ and in accordance with our previous data, upon CD10 expression, ${ }^{7}$ ICOS was considered as positive when expressed by at least 5\% of CD4-positive cells presumed as neoplastic $\mathrm{T}$ cells. PD-1 expression by $\mathrm{T}$ cells is common and a threshold of $20 \%$, usually used in flow cytometry, was chosen. The fluorescence level of each parameter was also measured in arbitrary units such as the mean fluorescence intensity (MFI) and the ratio of fluorescence intensity (RFI) corresponding to the MFI of neoplastic $\mathrm{T}$ cells normalized to the MFI of the residual $\mathrm{T}$ cells. 


\begin{tabular}{|c|c|c|c|c|c|c|c|c|c|}
\hline Cases & Age/sex & Cliniq & & Phénotype (CMF) & CD10 (CMF) & CD10 & TCR & BCR & \\
\hline 1 & $68 / \mathrm{F}$ & $\begin{array}{l}\text { Generalized lymphadenopathy, } \\
\text { anemia }\end{array}$ & Hypogammaglobulinemia & $\mathrm{LN}: \mathrm{CD}^{+} / \mathrm{CD}^{+} / \mathrm{CD}^{+(\mathrm{b})} / \mathrm{CD}^{+} / \mathrm{CD}^{+}$ & Pos $(10 \%)$ & Pos (2) & + & NA & \\
\hline 2 & $48 / \mathrm{M}$ & $\begin{array}{l}\text { Generalized lymphadenopathy, } \\
\text { fatigue, pruritus, anemia }\end{array}$ & Hypogammaglobulinemia & $\begin{array}{l}\mathrm{LN}: \mathrm{CD3}^{-} / \mathrm{CD}^{+} / \mathrm{CD}^{+} / \mathrm{CD}^{+} / \mathrm{CD}^{+} \\
\mathrm{PB}: \mathrm{CD3}^{-} / \mathrm{CD}^{+} / \mathrm{CD}^{+} / \mathrm{CD}^{+} / \mathrm{CD}^{+(\mathrm{d})}\end{array}$ & $\begin{array}{l}\text { Pos }(25 \%) \\
\text { Pos }(5 \%)\end{array}$ & Pos (2) & + & + & \\
\hline 3 & $55 / F$ & $\begin{array}{l}\text { Lymphadenopathy, SN, skin lesions, } \\
\text { anemia }\end{array}$ & Hyper gammaglobulinemia & $\begin{array}{l}\mathrm{LN}: \mathrm{CD}^{+} / \mathrm{CD}^{+} / \mathrm{CD}^{+} / \mathrm{CD}^{+} / \mathrm{CD}^{+} \\
S N: C D 3^{+} / C D 4^{+} / C D 2^{+} / C D 5^{+} / C D 7^{+}\end{array}$ & $\begin{array}{l}\text { Pos }(22 \%) \\
\text { Pos }(8 \%)\end{array}$ & Pos (2) & $\begin{array}{l}+ \\
+\end{array}$ & $\begin{array}{l}- \\
-\end{array}$ & \\
\hline 4 & $58 / \mathrm{F}$ & $\begin{array}{l}\text { Generalized lymphadenopathy, fever, } \\
\text { hemolytic anemia }\end{array}$ & Hyper gammaglobulinemia & $\mathrm{LN}: \mathrm{CD}^{+} / \mathrm{CD}^{+} / \mathrm{CD}^{+} / \mathrm{CD}^{+} / \mathrm{CD}^{+}$ & Pos $(16 \%)$ & Pos (2) & + & + & \\
\hline 5 & $51 / \mathrm{M}$ & $\begin{array}{l}\text { Generalized lymphadenopathy, } \\
\text { splenomegaly, skin lesions, fever, } \\
\text { anemia }\end{array}$ & $\begin{array}{l}\text { Hyper gammaglobulinemia } \\
\text { (IgG } \kappa=24 \mathrm{~g} / \mathrm{l})\end{array}$ & $\begin{array}{l}\mathrm{LN}: \mathrm{CD3}^{-} / \mathrm{CD}^{+} / \mathrm{CD}^{+} / \mathrm{CD}^{+} / \mathrm{CD}^{+} \\
\mathrm{PB}: \mathrm{CD3}^{-} / \mathrm{CD}^{+} / \mathrm{CD}^{+} / \mathrm{CD}^{+} / \mathrm{CD}^{+}\end{array}$ & $\begin{array}{l}\text { Pos }(27 \%) \\
\text { Pos }(34 \%)\end{array}$ & Pos (3) & $\stackrel{+}{\mathrm{NA}}$ & $\begin{array}{l}\text { NA } \\
\text { NA }\end{array}$ & \\
\hline 6 & $55 / \mathrm{M}$ & $\begin{array}{l}\text { Generalized lymphadenopathy, skin } \\
\text { lesions, anemia }\end{array}$ & Hypogammaglobulinemia & $\begin{array}{l}\mathrm{LN}: \mathrm{CD}^{+} / \mathrm{CD}^{+} / \mathrm{CD}^{+(\mathrm{d})} / \mathrm{CD}^{+(\mathrm{d})} / \mathrm{CD}^{+(\mathrm{d})} \\
\mathrm{PB}: \mathrm{CD}^{+} / \mathrm{CD}^{+} / \mathrm{CD}^{+(\mathrm{d})} / \mathrm{CD}^{+(\mathrm{d})} / \mathrm{CD}^{+(\mathrm{d})}\end{array}$ & $\begin{array}{l}\text { Pos }(27 \%) \\
\text { Pos }(5 \%)\end{array}$ & Pos (2) & $\stackrel{+}{\mathrm{NA}}$ & $\stackrel{+}{\mathrm{NA}}$ & \\
\hline 7 & $68 / \mathrm{F}$ & $\begin{array}{l}\text { Lymphadenopathy, fever, skin lesions, } \\
\text { anemia }\end{array}$ & Hypogammaglobulinemia & $\mathrm{LN}: \mathrm{CD}^{+} / \mathrm{CD}^{+} / \mathrm{CD}^{+} / \mathrm{CD}^{+} / \mathrm{CD}^{+(\mathrm{d})}$ & Pos $(26 \%)$ & Pos (2) & + & NA & \\
\hline 8 & $82 / \mathrm{M}$ & $\begin{array}{l}\text { Generalized lymphadenopathy, } \\
\text { splenomegaly, anemia }\end{array}$ & $\begin{array}{l}\text { Hypogammaglobulinemia } \\
\text { (IgG } \kappa=33 \mathrm{~g} / \mathrm{l} \text { ) }\end{array}$ & $\begin{array}{l}\mathrm{LN}: \mathbf{C D 3}^{-} / \mathbf{C D 4}^{-} / \mathrm{CD}^{+} / \mathrm{CD}^{+} / \mathrm{CD}^{+} \\
\mathrm{PB}: \mathbf{C D 3}^{-} / \mathbf{C D 4}^{-} / \mathrm{CD}^{+} / \mathrm{CD}^{+} / \mathrm{CD}^{+}\end{array}$ & $\begin{array}{l}\text { Pos }(58 \%)^{*} \\
\text { Pos }(47 \%)^{*}\end{array}$ & Pos (3) & $\begin{array}{l}+ \\
+\end{array}$ & $\begin{array}{l}- \\
-\end{array}$ & \\
\hline 9 & $59 / \mathrm{M}$ & $\begin{array}{l}\text { Generalized lymphadenopathy, } \\
\text { anemia }\end{array}$ & Hyper gammaglobulinemia & $\begin{array}{l}\mathrm{LN}: \mathrm{CD}^{+} / \mathrm{CD}^{+} / \mathrm{CD}^{+} / \mathrm{CD}^{+} / \mathrm{CD}^{+} \\
\mathrm{PB}: \mathrm{CD}^{+} / \mathrm{CD}^{+} / \mathrm{CD}^{+} / \mathrm{CD}^{+} / \mathrm{CD}^{+}\end{array}$ & $\begin{array}{l}\text { Pos }(16 \%) \\
\text { Pos }(17 \%)\end{array}$ & Pos (2) & $\begin{array}{l}+ \\
+\end{array}$ & $\overline{\mathrm{NA}}$ & \\
\hline 10 & $72 / \mathrm{M}$ & $\begin{array}{l}\text { Generalized lymphadenopathy, } \\
\text { splenomegalia, anemia }\end{array}$ & Hyper gammaglobulinemia & $\begin{array}{l}\mathrm{LN}: \mathrm{NA} \\
\mathrm{BM}: \mathrm{CD}^{+} / \mathrm{CD}^{+} / \mathrm{CD}^{+} / \mathrm{CD}^{+} / \mathrm{CD}^{+}\end{array}$ & $\begin{array}{l}\text { ND } \\
\text { Pos }(5 \%)\end{array}$ & Pos (2) & $\stackrel{+}{\mathrm{NA}}$ & $\begin{array}{l}\text { NA } \\
\text { NA }\end{array}$ & \\
\hline 11 & $38 / F$ & $\begin{array}{l}\text { Lymphadenopathy, hemolytic } \\
\text { anemia }\end{array}$ & Hyper gammaglobulinemia & $\mathrm{LN}: \mathrm{CD}^{+} / \mathrm{CD}^{+} / \mathrm{CD}^{+} / \mathrm{CD}^{+} / \mathrm{CD}^{+}$ & Neg & Neg (0) & - & - & \\
\hline 12 & $62 / \mathrm{F}$ & Lymphadenopathy, anemia & Hyper gammaglobulinemia & $\begin{array}{l}\mathrm{LN}: \mathrm{CD}^{+} / \mathrm{CD}^{+} / \mathrm{CD}^{+} / \mathrm{CD}^{+} / \mathrm{CD}^{+(\mathrm{d})} \\
\mathrm{PB}: \mathrm{CD}^{+} / \mathrm{CD}^{+} / \mathrm{CD}^{+} / \mathrm{CD}^{+} / \mathrm{CD}^{+(\mathrm{d})}\end{array}$ & $\begin{array}{l}\text { Pos }(23 \%) \\
\text { Pos }(20 \%)\end{array}$ & Pos (3) & $\begin{array}{l}+ \\
+\end{array}$ & $\begin{array}{l}+ \\
-\end{array}$ & 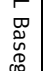 \\
\hline 13 & $69 / \mathrm{M}$ & $\begin{array}{l}\text { Generalized lymphadenopathy, } \\
\text { splenomegalia, pruritus. }\end{array}$ & NA & $\begin{array}{l}\mathrm{LN}: \mathrm{CD}^{+} / \mathrm{CD}^{+} / \mathrm{CD}^{+} / \mathrm{CD}^{+} / \mathrm{CD}^{+} \\
\mathrm{PB}: \mathrm{CD}^{+} / \mathrm{CD}^{+} / \mathrm{CD}^{+} / \mathrm{CD}^{+} / \mathrm{CD}^{+}\end{array}$ & $\begin{array}{l}\text { Pos }(15 \%) \\
\text { Pos }(9 \%)\end{array}$ & Pos (3) & $\begin{array}{l}+ \\
+\end{array}$ & $\stackrel{+}{\mathrm{NA}}$ & 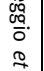 \\
\hline 14 & $69 / \mathrm{M}$ & $\begin{array}{l}\text { Generalized lymphadenopathy, } \\
\text { splenomegalia, anemia }\end{array}$ & NA & $\begin{array}{l}\mathrm{LN}: \mathrm{CD3}^{-} / \mathrm{CD}^{+} / \mathrm{CD}^{+} / \mathrm{CD}^{+} / \mathrm{CD}^{+} \\
\mathrm{PB}: \mathrm{CD3}^{-} / \mathrm{CD}^{+} / \mathrm{CD}^{+} / \mathrm{CD}^{+} / \mathrm{CD}^{+}\end{array}$ & $\begin{array}{l}\text { Pos }(40 \%) \\
\text { Pos }(5 \%)\end{array}$ & Pos (3) & $\stackrel{+}{\mathrm{NA}}$ & $-\overline{N A}$ & $\stackrel{2}{2}$ \\
\hline 15 & $60 / \mathrm{F}$ & $\begin{array}{l}\text { Lymphadenopathy, splenomegalia, } \\
\text { anemia }\end{array}$ & NA & $\begin{array}{l}\mathrm{LN}: \mathrm{CD}^{+} / \mathrm{CD}^{+} / \mathrm{CD}{ }^{+} / \mathrm{CD}^{+} / \mathrm{CD}^{+} \\
\mathrm{PB}: \mathrm{CD}^{+} / \mathrm{CD}^{+} / \mathrm{CD}^{+} / \mathrm{CD}^{+} / \mathrm{CD}^{+}\end{array}$ & $\begin{array}{l}\text { Pos }(9 \%) \\
\text { Neg }\end{array}$ & Pos (2) & - & $\overline{\mathrm{NA}}$ & \\
\hline 16 & $59 / \mathrm{F}$ & $\begin{array}{l}\text { Generalized lymphadenopathy, } \\
\text { splenomegalia, skin lesions. }\end{array}$ & NA & $\begin{array}{l}\mathrm{LN}: \mathrm{NA} \\
\text { PB: } \mathrm{CD3}^{-} / \mathrm{CD}^{+} / \mathrm{CD}^{+} / \mathrm{CD}^{+} / \mathrm{CD}^{+}\end{array}$ & & $\begin{array}{l}\text { Neg }(0) \\
(\text { Bcl-6+) }\end{array}$ & $\begin{array}{l}+ \\
+\end{array}$ & $\begin{array}{l}\text { NA } \\
\text { NA }\end{array}$ & \\
\hline 17 & $69 / \mathrm{F}$ & $\begin{array}{l}\text { Generalized lymphadenopathy, } \\
\text { splenomegalia, anemia, pruritus. }\end{array}$ & NA & $\begin{array}{l}\mathrm{LN}: \mathrm{CD}^{+} / \mathrm{CD}^{+} / \mathrm{CD}^{+} / \mathrm{CD}^{+} / \mathrm{CD}^{+} \\
\mathrm{PB}: \mathrm{CD}^{+} / \mathrm{CD}^{+} / \mathrm{CD}^{+} / \mathrm{CD}^{+} / \mathrm{CD}^{+}\end{array}$ & $\begin{array}{l}\text { Pos }(15 \%) \\
\text { Pos }(5 \%)\end{array}$ & Pos (1) & $\stackrel{+}{\mathrm{NA}}$ & $\begin{array}{l}\text { NA } \\
\text { NA }\end{array}$ & \\
\hline 18 & $63 / \mathrm{M}$ & $\begin{array}{l}\text { Generalized lymphadenopathy, } \\
\text { splenomegalia, anemia }\end{array}$ & Hypogammaglobulinemia & $\begin{array}{l}\mathrm{LN}: \mathrm{CD3}^{-} / \mathrm{CD}^{+} / \mathrm{CD}^{+(\mathrm{b})} / \mathrm{CD}^{+} / \mathrm{CD}^{+(\mathrm{d})} \\
\mathrm{PB}: \mathrm{CD3}^{-} / \mathrm{CD}^{+} / \mathrm{CD}^{+(\mathrm{b})} / \mathrm{CD}^{+} / \mathrm{CD}^{+(\mathrm{d})}\end{array}$ & $\begin{array}{l}\text { Neg } \\
\text { Neg }\end{array}$ & $\begin{array}{l}\text { Neg }(0) \\
\text { (Bcl-6+) }\end{array}$ & $\stackrel{+}{\mathrm{NA}}$ & $\begin{array}{l}\text { NA } \\
\text { NA }\end{array}$ & \\
\hline 19 & $76 / \mathrm{F}$ & $\begin{array}{l}\text { Generalized lymphadenopathy, } \\
\text { anemia, skin lesions. }\end{array}$ & Hyper gammaglobulinemia & $\mathrm{LN}: \mathrm{CD3}^{-} / \mathrm{CD}^{+} / \mathrm{CD}^{+} / \mathrm{CD}^{+} / \mathrm{CD}^{+}$ & Pos $(14 \%)$ & Pos (2) & + & - & \\
\hline 20 & $64 / \mathrm{M}$ & $\begin{array}{l}\text { Lymphadenopathy, splenomegalia, } \\
\text { anemia }\end{array}$ & Hyper gammaglobulinemia & $\mathrm{LN}: \mathrm{CD}^{+} / \mathrm{CD} 4^{+} / \mathrm{CD}^{+} / \mathrm{CD}^{+} / \mathrm{CD}^{+}$ & Pos $(74 \%)$ & Pos (3) & NA & NA & \\
\hline 21 & $68 / \mathrm{M}$ & Lymphadenopathy, anemia & $\begin{array}{l}\text { Hyper gammaglobulinemia } \\
\text { (IgM) }\end{array}$ & $\begin{array}{l}\mathrm{LN}: \mathrm{CD}^{+} / \mathrm{CD}^{+} / \mathrm{CD}{ }^{+} / \mathrm{CD}^{+} / \mathrm{CD}^{+} \\
\mathrm{PB}: \mathrm{CD}^{+} / \mathrm{CD}^{+} / \mathrm{CD}^{+} / \mathrm{CD}^{+} / \mathrm{CD}^{+}\end{array}$ & $\begin{array}{l}\text { Pos }(33 \%) \\
\text { Pos }(5 \%)\end{array}$ & Pos (2) & $\stackrel{+}{\mathrm{NA}}$ & $\begin{array}{l}\text { NA } \\
\text { NA }\end{array}$ & \\
\hline 22 & $50 / \mathrm{F}$ & $\begin{array}{l}\text { Generalized lymphadenopathy, } \\
\text { hemolytic anemia }\end{array}$ & $\begin{array}{l}\text { Hyper gammaglobulinemia } \\
\text { (IgM) }\end{array}$ & $\begin{array}{l}\mathrm{LN}: \mathrm{CD}^{+} / \mathrm{CD}^{+} / \mathrm{CD}^{+} / \mathrm{CD}^{+} / \mathrm{CD}^{+} \\
\mathrm{PB}: \mathrm{CD}^{+} / \mathrm{CD}^{+} / \mathrm{CD}^{+} / \mathrm{CD}^{+} / \mathrm{CD}^{+}\end{array}$ & $\begin{array}{l}\text { Pos }(12 \%) \\
\text { Pos }(5 \%)\end{array}$ & $\begin{array}{l}\text { Pos (2), } \\
\text { (Bcl-6+) }\end{array}$ & $\begin{array}{l}+ \\
+\end{array}$ & $\begin{array}{l}- \\
-\end{array}$ & \\
\hline 23 & $58 / \mathrm{M}$ & Lymphadenopathy, anemia & Normal & $\begin{array}{l}\mathrm{LN}: \mathrm{CD3}^{-} / \mathrm{CD}^{+} / \mathrm{CD}{ }^{+} / \mathrm{CD}^{+} / \mathrm{CD}^{+} \\
\mathrm{PB}: \mathrm{CD3}^{-} / \mathrm{CD}^{+} / \mathrm{CD}^{+} / \mathrm{CD}^{+} / \mathrm{CD}^{+}\end{array}$ & $\begin{array}{l}\text { Pos }(5 \%) \\
\text { Pos }(5 \%)\end{array}$ & Pos (2) & $\stackrel{+}{\mathrm{NA}}$ & $\begin{array}{l}\text { NA } \\
\text { NA }\end{array}$ & \\
\hline 24 & $91 / \mathrm{F}$ & $\begin{array}{l}\text { Generalized lymphadenopathy, } \\
\text { anemia }\end{array}$ & Normal & $\mathrm{LN}: \mathrm{CD}^{+} / \mathrm{CD}^{+} / \mathrm{CD}^{+} / \mathrm{CD}^{+} / \mathrm{CD}^{+}$ & Pos $(13 \%)$ & Pos (2) & - & - & \\
\hline
\end{tabular}




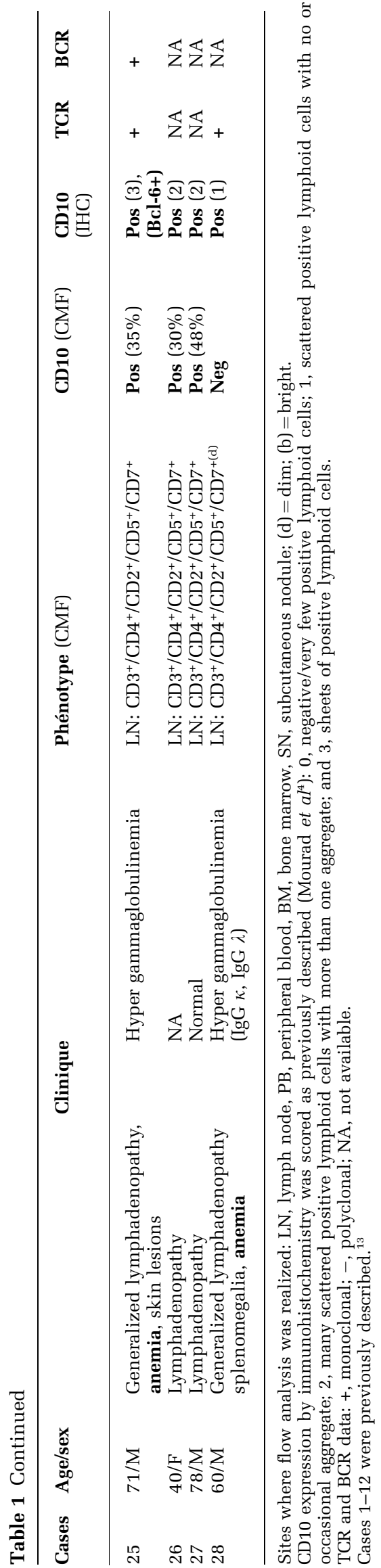

\section{Molecular Study}

DNA was extracted from tissue or cell suspensions using High Pure PCR Template Preparation Kit (Roche, Mannheim, Germany). T-cell receptor $\gamma$-chain gene rearrangements were studied using a GC-clamp multiplex PCR- $\gamma$-DGGE procedure as previously described $^{20}$ and the immunoglobulin (Ig) gene rearrangements by multiplex PCR using consensus primers from European BIOMED-2 concerted action. ${ }^{21}$

\section{Results}

\section{Clinical and Biological Data}

The patients (15 men and 13 women) ranged in age from 40 to 91 years (median 62 years). All patients presented with generalized lymphadenopathy and the detailed clinical data summarized in Table 1 are in keeping with previous large series of angioimmunoblastic T-cell lymphomas. ${ }^{4}$

Laboratory investigations showed anemia in most cases $(24 / 28(86 \%))$. Hypergammaglobulinemia was present in 13 cases (59\%), hypogammaglobulinemia in 6 cases $(27 \%)$ and 3 cases presented a normal immunoglobulin profile $(14 \%)$. In four cases (one case with hypogammaglobulinemia and three with hypergammaglobulinemia), a monoclonal component was found in the serum. At the time of lymph node biopsy, seven cases showed a normal value of lymphocytes (mean $1.34 \times 10^{9} /$ l (range 1.10-3.37)) A lymphopenia (lymphocyte $<1.00 \times 10^{9} /$ l) was present in 21 of 28 cases $(68 \%)$, concerning more particularly B-cell lymphopenia (mean $=0.05 \times 10^{9} / 1$ (range 0.01-1.14)). Hypereosinophilia, $>0.50 \times 10^{9} / \mathrm{l}$, was observed in three cases only. The bone marrow (biopsy and smears) was infiltrated by lymphoma in 12 of the 14 available cases (9 of them studied simultaneously in peripheral blood). In all available cases but one, cytological analysis of peripheral blood smears showed atypical lymphoid cells.

In the 25 available lymph node cases, 22 cases presented a monoclonal rearrangement of T-cell receptor by PCR. In the six cases that were studied simultaneously in peripheral blood and lymph nodes, an identical T-cell receptor gene rearrangement was found. Of the 15 available lymph node samples, 6 also showed a minor B-cell clone.

Follow-up was available in 19 cases with a median of 22 months (range 5-133 months): 11 patients were still alive at the end of the study and 8 patients died of the disease. A relapse occurred in 15 of the 19 cases with a median of 6 months (range 1-84 months) after the diagnosis.

\section{Immunological Data}

Immunological profile of the neoplastic T cells In this series, all presumed neoplastic T cells were CD4 positive, except one case that showed a CD4/ 
CD8 double-negative phenotype. In 8 cases studied in lymph node and peripheral blood (8/28 (28\%)), neoplastic $\mathrm{T}$ cells were recognized thanks to a complete loss of surface CD3 antigen (while expressing cytoplasmic CD3 antigen). In all nodal samples, pan-T-cell markers CD7, CD5 and CD2 were always positive but with a lower expression than in residual T cells in only 6, 1 and 1 cases, respectively (Table 1). Two cases showed an increased CD2 expression. In all peripheral blood samples but one, malignant $\mathrm{T}$ cells showed the same immunological pattern than in lymph node samples. In this last case, the CD7 expression was weaker in peripheral blood than in lymph node sample. In addition, in all angioimmunoblastic T-cell lymphoma cases analyzed in lymph node suspension as well as in peripheral blood, neoplastic T cells were CD57 and CD25 negative and CD45RO positive.

In summary, 13 of the 28 cases showed an abnormal T-cell phenotype. Among lymph node samples, CD2 and CD5 were the less commonly downregulated antigens $(n=1)$, and the other pan-T antigens were aberrantly lacking (CD3, $n=8$ ) or diminished (CD3, $n=1$; CD7, $n=6$ ) or increased (CD2, $n=2)$. The immunological pattern was identical in all corresponding peripheral blood samples but one.

\section{CD10 Expression}

As previously demonstrated, ${ }^{7}$ most cases analyzed by flow cytometry in lymph node suspension showed a fraction of $\mathrm{T}$ cells that coexpressed CD10 (23/26 (88\%); Table 1). A good correlation between flow and immunohistochemistry was found again, as only one case (case no. 28) was discordant (CD10 negative by flow and dimly positive by immunohistochemistry). Among all lymph node cases, 15 could also be studied in peripheral blood, and circulating CD10-positive $T$ cells were observed in 12/15 cases $(80 \%)$. Among the three CD10-negative cases in peripheral blood, one case was CD10 positive in lymph node, but only a small fraction of CD4 T cells expressed CD10 (9\% by flow and few scattered CD10-positive $\mathrm{T}$ cells with no aggregate by immunohistochemistry; case no. 15). In this case, no T-cell clone was identified by PCR in lymph node, whereas a very minor T-cell clone was observed in peripheral blood. The two other cases (case nos. 16 and 18) were also CD10 negative in lymph node (flow cytometry and/or immunohistochemistry). However, the presence of neoplastic T cells in blood was attested by a monoclonal rearrangement of $\mathrm{T}$ cell receptor by PCR (case no. 16) and by atypical immunological T-cell profile (lack of surface CD3; case no. 18). In two extranodal sites (bone marrow and skin nodule), CD10-positive $\mathrm{T}$ cells were also identified.

In summary, neoplastic T cells expressed CD10 in $23 / 26$ of lymph nodes (88\%), 2/2 of extranodal sites $(100 \%)$ and $12 / 15$ peripheral blood samples $(80 \%)$, whereas no significant CD10-positive T cells were identified in the control group (lymph nodes, $n=10$ and peripheral blood, $n=15)$. In addition, the CD10 expression was positive in 14 of the 15 cases with normal T-cell phenotype, which substantiate the involvement by neoplastic T cells.

\section{Expression of the $\mathbf{T}_{\mathbf{F H}}$ Markers}

First, the effect of cryopreservation and thawing on the ICOS and PD-1 expression by $\mathrm{T}$ cells was evaluated on several thawed samples (angioimmunoblastic T-cell lymphoma and negative control group) that had been cryopreserved for up to 9 years. The ICOS and PD-1 expressions were not modified by cryopreservation and thawing (data not shown).

\section{ICOS and PD-1 expression in lymph node}

Of the 15 lymph node suspensions, 13 (87\%) were ICOS positive using a threshold of $5 \%$ of CD4 T cells (Figure 1 and Table 2). In the control group (reactive lymph nodes, $n=10$ ), no CD4-positive $\mathrm{T}$ cells expressed ICOS using a cutoff of 5\% (range 0-2\%). In addition, the median of ICOS MFI in angioimmunoblastic T-cell lymphoma-positive cases was 164 (range 86-704), which was statistically higher than the MFI of the reactive lymph nodes (46 (range 2982); $P<0.05$; Figure 2a). In the same way, the ratio of ICOS MFI was also informative, as this ratio was 3.15 (range 1.19-6.82) in angioimmunoblastic T-cell lymphoma cases, whereas it was 1.14 (range $0.70-$ $2.20)$ in reactive lymph nodes $(P<0.05$; Figure $2 \mathrm{~b})$.

Using a cutoff of $20 \%, 14 / 15$ angioimmunoblastic T-cell lymphoma cases (93\%) were PD-1 positive (median of $\mathrm{MFI}=7059$ (range 3857-28 942), ratio $=2.58$ (range 1.33-6.28); Figure 1), whereas 6/ $10(60 \%)$ cases were PD-1 positive in reactive hyperplasia (median of $\mathrm{MFI}=1853$ (range 9686847], ratio $=1.92$ (range $0.85-2.48$ )). The PD-1 expression was not significantly different between angioimmunoblastic T-cell lymphoma cases and control group. As the PD-1 expression when expressed as MFI or RFI appears higher in angioimmunoblastic T-cell lymphoma cases than in control cases, a threshold of $40 \%$ was tested (data not shown), but this cutoff of $40 \%$ was not more informative to discriminate angioimmunoblastic Tcell lymphoma from reactive conditions. The PD-1negative case was positive for both CD10 and ICOS.

In the lymph node case that was CD10 negative by flow and immunohistochemistry (case no. 18), ICOS was strongly expressed $(24 \%, M F I=159$ and ratio $=3.53)$ as well as $\mathrm{PD}-1(81 \%, \mathrm{MFI}=5744$ and ratio $=1.33)$. In the present series, no case was negative for both ICOS and CD10.

In 10/15 angioimmunoblastic T-cell lymphoma cases $(67 \%)$, a subset of neoplastic $\mathrm{T}$ cells $(>5 \%)$ that coexpressed CD10/ICOS/PD-1 could be identified (Figure 3a), whereas no cases of the control 
group showed this subset of T cells $(<5 \%$; (range $0.1-5 \%)$ ). Interestingly, among the $5 / 15$ lymph node cases without significant CD10/ICOS/PD-1-positive T cells, 2 were positive for both CD10 and ICOS, 2 were only positive for CD10 and 1 was only positive for ICOS. In this last case, an abnormal T-cell profile was observed as well as a monoclonal rearrangement of T-cell receptor by PCR that confirmed the presence of neoplastic T cells. The two cases, which were positive for both CD10 and ICOS but without CD10/ICOS/PD-1 coexpressing T cells, presented an aberrant T-cell profile with lack of surface CD3 expression and/or monoclonal rearrangement of $\mathrm{T}$ cell receptor.

ICOS and PD-1 expression in peripheral blood Among the 13 peripheral blood analyzed for the ICOS expression, 6/13 (47\%) cases were considered positive with a cutoff of $5 \%$ (median $\mathrm{MFI}=64$ (range 40-830), ratio $=3.11$ (range 1.67-16.70), whereas no cases of the control group expressed ICOS (in all cases: ICOS expression $<5 \%$ (range $0-1.5 \%$ ); median of $\mathrm{MFI}=33$ (range 13-52), ratio $=0.90$ (range 0.90-2.6); $P<0.05$; Figures 1 and 2 and Table 2).

Using a cutoff of $20 \%, 12 / 13(92 \%)$ angioimmunoblastic T-cell lymphoma cases were PD-1 positive (median of $\mathrm{MFI}=2666$ (range 607-6660), ratio $=2.68$ (range $0.86-3.74)$ ), whereas 11/15 $(73 \%)$ control cases were positive for PD-1 (median of $\mathrm{MFI}=760$ (range 124-3578), ratio $=0.63$ (range $0.08-1.45)$ ). A cutoff of $40 \%$ was also tested but was not discriminative (data not shown).

Interestingly, among the three CD10-negative peripheral blood cases, one was ICOS positive $(>5 \%$ of $\mathrm{CD} 4 \mathrm{~T}$ cells $\mathrm{MFI}=40$, ratio $=5)$ whereas
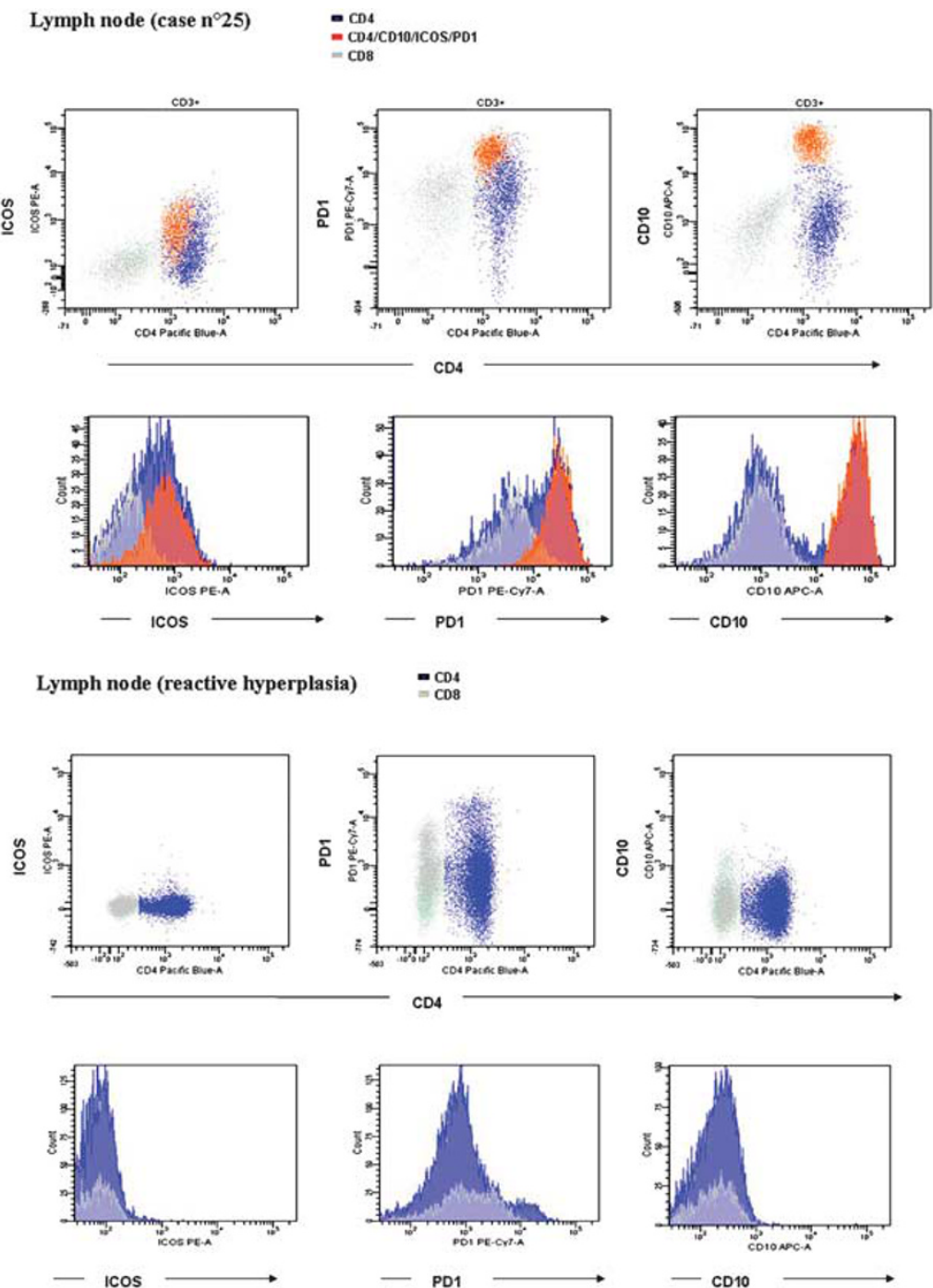

Figure 1 Flow representation of ICOS, PD-1 and CD10 expression by neoplastic T cells. The eight-color flow cytometric immunophenotyping is performed using CD5, CD3 and CD4 antibodies that allow for selective gating on the T cells, in combination with ICOS, PD-1 and CD10. From left to right: representative flow cytometry dot plot (upper line) and histogram (lower line) gated on lymphocytes. 

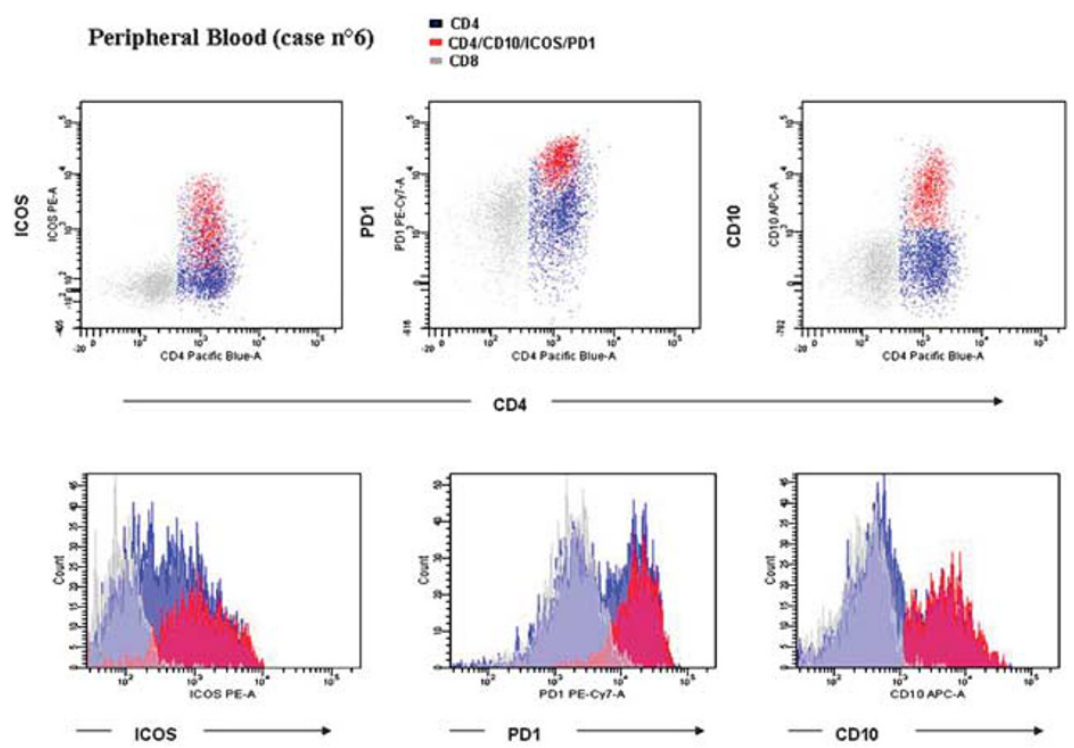

$\begin{aligned} \text { Peripheral Blood (healthy donors) } & =\mathrm{CDA} \\ & =\mathrm{COB}\end{aligned}$
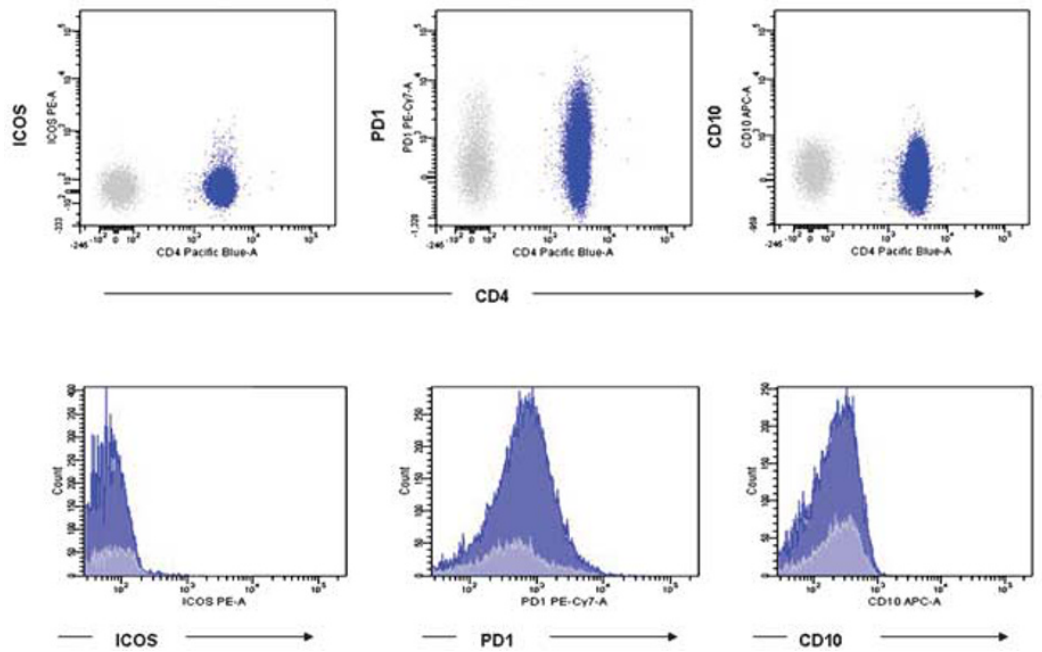

Figure 1 Continued.

all T-cell markers were normally expressed. All three cases were PD- 1 positive $(>20 \%$ of CD4 T cells, $\mathrm{MFI}=1956$, ratio $=1.57$ ).

In the 13 peripheral blood cases, 3 cases presented a subset of CD4-positive T cells ( $>5 \%$ of CD4 T cells), which coexpressed the three markers CD10/ ICOS/PD-1 (Figure 3b), whereas no CD4/CD10/ ICOS/PD-1-positive $\mathrm{T}$ cells were identified in the control group $(0 \%)$. In the 10 cases without significant CD10/ICOS/PD-1-positive T cells, 2 were positive for both CD10 and ICOS, 2 were negative for both, 5 were positive for CD10 and negative for ICOS and 1 was negative for CD10 and positive for ICOS.

Eight pairs (lymph node and peripheral blood) were studied at the same time. Only one case was CD10 negative in both lymph node and peripheral blood. In this case, ICOS was positive in lymph node but negative in peripheral blood, whereas circulating neoplastic $\mathrm{T}$ cells were confirmed by
T-cell clone by PCR and abnormal T-cell profile (lack of surface CD3 expression) by flow cytometry. Of the eight cases, seven $(87.5 \%)$ were CD10 positive for both lymph node and peripheral blood. Among the 7 CD10-positive lymph node cases, 6/7 (85.7\%) were ICOS positive in lymph node, but only 2 of these 6 cases $(33 \%)$ were ICOS positive in peripheral blood.

Moreover, in cases with neoplastic $\mathrm{T}$ cells in particular defined by atypical T-cell profile such as lack of surface CD3, multiparametric flow cytometry allows to identify in lymph node and peripheral blood specimens different subsets of tumoral T cells based on CD10 and ICOS expression: one that coexpressed the two markers (CD10/ICOS), one only the CD10 and one only the ICOS protein. These results suggest that the neoplastic $\mathrm{T}$ cells in angioimmunoblastic T-cell lymphoma could be composed of immunologically different cell populations and that the subset of CD10-positive T cells 
Table 2 CD10, ICOS and PD1 expression in AITL cases

\begin{tabular}{|c|c|c|c|c|c|c|c|c|c|}
\hline \multirow[t]{2}{*}{ Cases } & \multirow[t]{2}{*}{ Sites } & \multirow[t]{2}{*}{ CD10/CD4 } & \multicolumn{3}{|c|}{ ICOS/CD4 } & \multicolumn{3}{|c|}{ PD1/CD4 } & \multirow{2}{*}{$\begin{array}{c}\text { ICOS/PD1/ } \\
\text { CD10/CD4 (\%) }\end{array}$} \\
\hline & & & $\%$ & MFI & Ratio & $\%$ & MFI & Ratio & \\
\hline \multirow[t]{2}{*}{2} & LN & Pos $(25 \%)$ & Pos $(6 \%)$ & 139 & 1.19 & Neg $(12 \%)$ & 1521 & 1.01 & 1 \\
\hline & $\mathrm{PB}$ & Pos (5\%) & Pos (5\%) & 64 & 2.37 & Pos $(28 \%)$ & 1202 & 1.33 & $<1$ \\
\hline 3 & $\mathrm{LN}$ & Pos $(25 \%)$ & Pos $(20 \%)$ & 225 & 4.50 & Pos $(77 \%)$ & 3857 & 1.33 & 9 \\
\hline 4 & LN & Pos $(16 \%)$ & Pos $(42 \%)$ & 484 & 3.20 & Pos $(69 \%)$ & 16132 & 3.42 & 11 \\
\hline 5 & $\mathrm{~PB}$ & Pos $(34 \%)$ & Pos $(20 \%)$ & 143 & 3.17 & Pos $(74 \%)$ & 6660 & 3.74 & 11 \\
\hline 6 & $\mathrm{~PB}$ & Pos $(5 \%)$ & Pos $(39 \%)$ & 830 & 16.6 & Pos $(63 \%)$ & 4117 & 1.75 & 29 \\
\hline \multirow[t]{2}{*}{8} & LN & Pos $(58 \%)^{a}$ & Pos $(38 \%)^{\mathrm{a}}$ & 704 & 4.11 & Pos $(95 \%)^{a}$ & 9764 & 2.71 & 54 \\
\hline & $\mathrm{PB}$ & $\operatorname{Pos}(47 \%)^{\mathrm{a}}$ & $\operatorname{Neg}(1 \%)^{\mathrm{a}}$ & 53 & 1.00 & Pos $(97 \%)^{\mathrm{a}}$ & 6577 & 3.71 & 1 \\
\hline \multirow[t]{2}{*}{9} & $\mathrm{LN}$ & Pos $(16 \%)$ & Pos $(15 \%)$ & 164 & 2.07 & Pos $(73 \%)$ & 4505 & 1.56 & 5 \\
\hline & $\mathrm{PB}$ & Pos $(17 \%)$ & $\operatorname{Neg}(0 \%)$ & 58 & 0.87 & $\operatorname{Neg}(19 \%)$ & 1361 & 1.03 & 1 \\
\hline \multirow[t]{2}{*}{12} & LN & Pos $(23 \%)$ & Pos $(21 \%)$ & 202 & 3.01 & Pos $(61 \%)$ & 6723 & 2.43 & 11 \\
\hline & $\mathrm{PB}$ & Pos $(20 \%)$ & Neg $(1 \%)$ & 68 & 1.17 & Pos $(45 \%)$ & 2342 & 2.43 & 1 \\
\hline 13 & PB & Pos (9\%) & Pos (6\%) & 60 & 1.67 & Pos $(56 \%)$ & 2201 & 3.05 & 5 \\
\hline \multirow[t]{2}{*}{14} & $\mathrm{LN}$ & Pos $(40 \%)$ & Pos $(33 \%)$ & 273 & 6.82 & Pos $(77 \%)$ & 10098 & 2.39 & 28 \\
\hline & $\mathrm{PB}$ & Pos $(5 \%)$ & Neg $(1 \%)$ & 36 & 0.70 & Pos $(20 \%)$ & 607 & 0.86 & $<1$ \\
\hline 15 & PB & Neg & Pos (6\%) & 40 & 5.00 & Pos $(34 \%)$ & 1956 & 1.57 & 1 \\
\hline 16 & $\mathrm{~PB}$ & Neg & Neg $(0 \%)$ & 28 & 0.62 & Pos $(25 \%)$ & 759 & 0.86 & $<1$ \\
\hline \multirow[t]{2}{*}{18} & $\mathrm{LN}$ & Neg & Pos $(24 \%)$ & 159 & 3.53 & Pos $(81 \%)$ & 5744 & 1.33 & 2 \\
\hline & PB & Neg & $\operatorname{Neg}(1 \%)$ & 29 & 1.45 & Pos $(82 \%)$ & 3045 & 2.68 & 0 \\
\hline 19 & LN & Pos $(14 \%)$ & Pos $(20 \%)$ & 164 & 3.09 & Pos $(72 \%)$ & 5270 & 1.89 & 2 \\
\hline 20 & $\mathrm{LN}$ & Pos $(74 \%)$ & Pos $(8 \%)$ & 82 & 2.50 & Pos $(32 \%)$ & 5413 & 3.5 & 6 \\
\hline \multirow[t]{2}{*}{21} & LN & Pos $(33 \%)$ & $\operatorname{Neg}(3 \%)$ & 96 & 3.55 & Pos $(40 \%)$ & 4201 & 3.14 & 3 \\
\hline & $\mathrm{PB}$ & Pos (5\%) & Neg (1\%) & 34 & 3.77 & Pos $(56 \%)$ & 2666 & 3.37 & 0 \\
\hline \multirow[t]{2}{*}{23} & $\mathrm{LN}$ & Pos $(5 \%)$ & Pos $(20 \%)$ & 208 & 2.93 & Pos $(63 \%)$ & 8611 & 5.77 & 9 \\
\hline & PB & Pos (5\%) & Pos $(20 \%)$ & 161 & 2.92 & Pos $(72 \%)$ & 5520 & 3.54 & 2 \\
\hline 24 & LN & Pos $(13 \%)$ & Neg $(2 \%)$ & 83 & 0.79 & Pos $(48 \%)$ & 21595 & 3.06 & 2 \\
\hline 25 & $\mathrm{LN}$ & Pos $(35 \%)$ & Pos $(26 \%)$ & 515 & 4.64 & Pos $(54 \%)$ & 7394 & 2.06 & 31 \\
\hline 27 & LN & Pos $(48 \%)$ & Pos $(20 \%)$ & 161 & 3.09 & Pos $(90 \%)$ & 28942 & 6.28 & 16 \\
\hline
\end{tabular}

Sites, sites where flow analysis was realized; LN, lymph node; PB, peripheral blood; MFI, mean fluorescence intensity; ratio, MFI of CD4/MFI of control.

${ }^{\mathrm{a} C D} 4$-negative case.

display a greater propensity to circulate than the subset of ICOS-positive T cells.

\section{Relationship of the ICOS expression and clinicobio- logical data}

ICOS expression by neoplastic $\mathrm{T}$ cells was not correlated with hypergammaglobulinemia or hypogammaglobulinemia, or with the presence of a B-cell clone or plasma cells or T/B-cell ratio in lymph nodes and the histological pattern.

\section{Discussion}

The diagnosis of angioimmunoblastic T-cell lymphoma by flow cytometry in lymph node or blood relies on the detection of CD10 expression by CD4positive $\mathrm{T}$ cells, with or without an abnormal expression of pan-T-cell markers. The CD10/CD4positive subset, often minor, may be lacking, or too small to be considered as significant. Thus, the need of additional criteria explains the search of other molecules specifically expressed by $\mathrm{T}_{\mathrm{FH}}$ cells that angioimmunoblastic T-cell lymphoma derives from.

As previously reported by immunohistochemistry, ${ }^{16,17}$ the majority of our angioimmunoblastic T-cell lymphoma cases analyzed in lymph node suspensions expressed ICOS protein (13/15 (87\%)), in contrast to the reactive lymph nodes $(0 / 10)$, which confirms its relevance to angioimmunoblastic T-cell lymphoma diagnosis, or broader to peripheral T-cell lymphoma with a $\mathrm{T}_{\mathrm{FH}^{-}}$-like profile. In our lymph node series, the frequency of CD10 and ICOS expression was quite similar (88 and $83 \%$, respectively). PD-1 expression by flow cannot be used alone as a marker of malignancy as it was expressed not only in the majority of angioimmunoblastic T-cell lymphoma cases (14/15 (93\%)), but also in reactive hyperplasia $(6 / 10(60 \%))$. Other studies have shown similar results and, furthermore, PD-1 has been identified in other T-cell or B-cell lymphomas, pointing that it does not constitute a specific marker for angioimmunoblastic T-cell lymphoma. ${ }^{15}$ These results confirmed the superiority of ICOS expression to PD-1 in angioimmunoblastic T-cell lymphoma diagnosis in lymph node and showed its easy detection by flow cytometry. If several angioimmunoblastic T-cell lymphoma cases were ICOS negative, its positivity in CD10-negative case is an interesting feature, leading to propose ICOS as an additional marker in angioimmunoblastic T-cell lymphoma diagnosis by flow that could be included in a multiparametric flow cytometry staining beside CD10. 
a

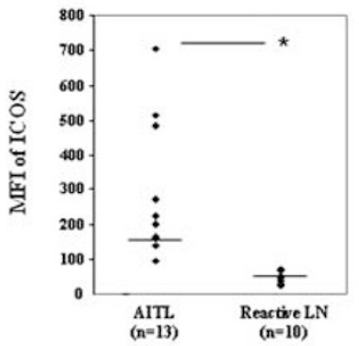

C

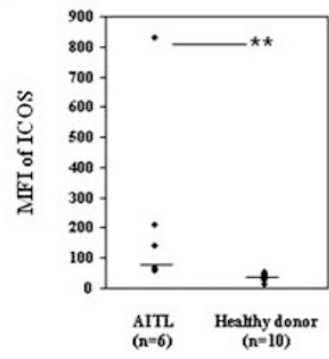

b

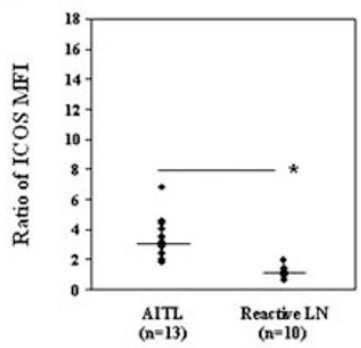

d

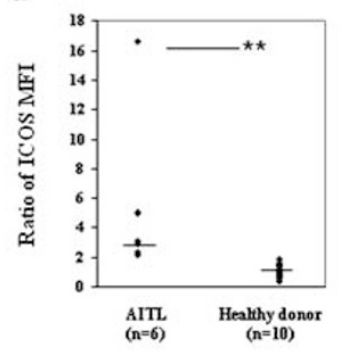

Figure 2 Median of fluorescence of ICOS (MFI) and ratio of MFI (RFI). The horizontal lines indicate the median of ICOS MFI and ratio of MFI. The ICOS MFI and the ratio of MFI are significantly higher in angioimmunoblastic T-cell lymphoma cases than in control group in lymph node suspensions as well as in peripheral blood. (a) ICOS MFI in lymph node samples (164 vs 46), (b) ratio of MFI in lymph node samples (3.15 vs 1.14), (c) ICOS MFI in peripheral blood samples (64 vs 33) and (d) ratio of MFI in peripheral blood samples (3.11 vs 0.90). Mann-Whitney $U$-test: ${ }^{*} P<0.0001 ;{ }^{*} P<0.001$

In keeping with our previous data and the literature, ${ }^{4,7,18}$ the blood dissemination in angioimmunoblastic T-cell lymphoma has been once again proven, as in all cases analyzed, blood smear analysis was very suggestive of circulating neoplastic $\mathrm{T}$ cells confirmed by monoclonal rearrangement of T-cell receptor by PCR and/or atypical T-cell phenotype, and more specifically by CD10 expression in most cases $(12 / 15(80 \%))$. In this peripheral blood series, the ICOS expression by flow appears less frequent than the CD10 expression, as it was observed in 6/13 cases (47\%). Nevertheless, its expression appears very specific of angioimmunoblastic T-cell lymphoma (or broader $\mathrm{T}_{\mathrm{FH}}$-derived lymphomas) as no circulating ICOS-positive T cells ( $>5 \%$ of CD4-positive $\mathrm{T}$ cells) were identified in peripheral blood of healthy donors in our series and literature. ${ }^{7,17}$ Interestingly, one case among the three CD10-negative cases was positive for ICOS. As shown in lymph node cases, the PD-1 expression alone was not specific in peripheral blood, as it was expressed by both angioimmunoblastic T-cell lymphoma and control peripheral blood.

The multiparametric flow cytometry methodology with appropriate gating is a very sensitive and specific approach that allows the detection of small cell populations characterized by specific coexpression of markers. This approach has been frequently

a
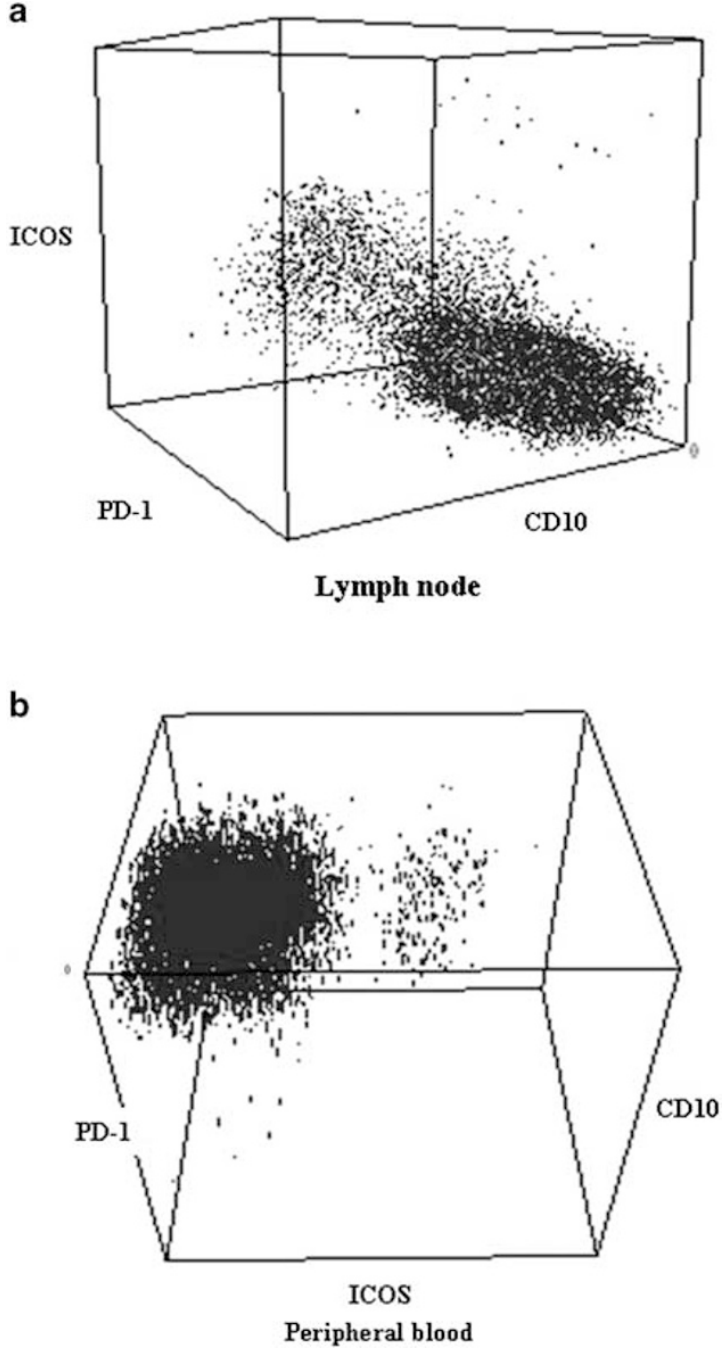

Figure 3 CD10/CD10/PD-1 coexpression by neoplastic T cells. A three-dimensional graph (tomogram) obtained by the software RXP (Beckman-Coulter) allows to identify easily a subset of neoplastic $\mathrm{T}$ cells that coexpress the three markers ICOS, PD-1 and CD10 in lymph node suspension (a, case no. 12) and in peripheral blood (b, case no. 4).

applied in the detection of minimal residual disease in different hematopoietic diseases. ${ }^{22,23}$ Thus, the use of an eight-color staining including the marker of malignancy (CD10) with markers of the cell origin ( $\mathrm{T}_{\mathrm{FH}}$ markers: PD-1 and ICOS) and pan-T-cell markers CD4/CD8/CD3/CD5 allows to identify a small subset of neoplastic $\mathrm{T}$ cells that coexpressed the three markers (CD10/ICOS/PD-1) in 10/15 lymph node cases and 3/13 peripheral blood cases. Interestingly, in one case, despite CD10 negativity $(<5 \%$ of $\mathrm{T}$ cells), a very minor subset (representing $2 \%$ of the CD4-positive T cells) that coexpressed the three markers (CD10/ICOS/PD-1) was identified in lymph node (Figure 3a). The presence of tumoral cells in this last case was confirmed by the detection of monoclonal rearrangement of T-cell receptor by PCR and an abnormal T-cell phenotype. These findings 
suggest that the significant level of tumoral cells may be decreased below $5 \%$ when at least ICOS and CD10 are coexpressed by $\mathrm{T}$ cells. Furthermore, in our lymph node series, when the presence of neoplastic $\mathrm{T}$ cells was demonstrated by an atypical T-cell profile such as lack of surface CD3, this sensitive approach suggests that neoplastic T cells could be composed of distinct immunological subsets: CD10 positive, ICOS positive, CD10/ICOS positive and CD10/ICOS negative. In addition, among the six ICOS/CD10-positive lymph node cases, only two cases were ICOS/CD10 positive in peripheral blood. The four other cases were CD10 positive but ICOS negative. In the same way, the case that was CD10 negative in lymph node and peripheral blood was ICOS positive in lymph node but ICOS negative in peripheral blood, although circulating neoplastic $\mathrm{T}$ cells were confirmed by monoclonal T cells by PCR and atypical phenotype of $\mathrm{T}$ cell (lack of surface CD3). These results highlight that the circulating population of neoplastic $\mathrm{T}$ cells consists more frequently in the CD10positive subset than in the ICOS-positive subset and emphasize that if ICOS could be a suitable angioimmunoblastic T-cell lymphoma marker in lymph node by immunohistochemistry and flow, it appears less contributive to detect circulating neoplastic $\mathrm{T}$ cells when used alone and must be integrated in a multiparametric staining. The true usefulness for PD-1 in the multiparametric approach could be questioned, as the relevance of the coexpression of CD10/ICOS with an appropriate gating appears similar to this of CD10/ICOS/PD-1 in all cases but one (case no. 18).

Finally, the $\mathrm{T}_{\mathrm{FH}}$ cells are believed to positively regulate B-cell differentiation and humoral immune responses during the germinal center reaction. This primary function results in increased levels of CD40L, ICOS and IL-10 (see refs. 24 and 25), and a high expression of ICOS probably defines the $\mathrm{T}_{\mathrm{FH}}$ cells able to induce immunoglobulin secretion by $\mathrm{B}$ cells. ${ }^{26,27}$ Thus, ICOS expression could contribute to the pathogenesis of angioimmunoblastic T-cell lymphoma, and in particular to hypergammaglobulinemia. However, in our series, no relationship between ICOS expression and clinical presentation was observed; in particular, cases without ICOS expression did not present uncommon features. However, this observation needs to be confirmed in larger series.

In conclusion, the detection of ICOS-positive $\mathrm{T}$ cells in lymph node suspension as well as in peripheral blood constitutes an additional feature for the diagnosis of angioimmunoblastic T-cell lymphoma. However, in peripheral blood, ICOS expression alone appears less sensitive than CD10 expression for the detection of circulating neoplastic $\mathrm{T}$ cells. These preliminary results substantiate the multiparametric flow analysis with appropriate gating and at least the two markers, CD10/ICOS, as a powerful approach for the identification of neoplastic T cells in lymph node as well as in peripheral blood that could be very contributive to angioimmunoblastic T-cell lymphoma diagnosis in association with clinical and morphological data.

\section{Disclosure/conflict of interest}

The authors declare no conflict of interest.

\section{References}

1 A clinical evaluation of the International Lymphoma Study Group classification of non-Hodgkin's lymphoma: by the Non-Hodgkin's Lymphoma Classification Project. Blood 1997;89:3909-3918.

2 Dogan A, Gaulard P, Jaffe E, et al. Angioimmunoblastic T-cell lymphoma. In: Swerdlow SH, Campo E, Harris NL et al. (eds). World Health Organization Classification of Tumours of Haematopoietic and Lymphoid Tissues, 4th edn. IARC Press: Lyon, 2008, pp 309-311.

3 Vose J, Armitage J, Weisenburger D, International TCell Lymphoma Project. International peripheral T-cell and natural killer/T-cell lymphoma study: pathology findings and clinical outcomes. J Clin Oncol 2008;26:4124-4130.

4 Mourad N, Mounier N, Brière J, , et al., Groupe d'Etude des Lymphomes de l'Adulte. Clinical, biologic, and pathologic features in 157 patients with angioimmunoblastic T-cell lymphoma treated within the Groupe d'Etude des Lymphomes de l'Adulte (GELA) trials. Blood 2008;111:4463-4467.

5 Attygalle A, Al-Jehani R, Diss TC, et al. Neoplastic T cells in angioimmunoblastic T-cell lymphoma express CD10. Blood 2002;99:627-633.

6 Attygalle AD, Diss TC, Munson P, et al. CD10 expression in extranodal dissemination of angioimmunoblastic T-cell lymphoma. Am J Surg Pathol 2004; 28:54-61.

7 Baseggio L, Berger F, Morel D, et al. Identification of circulating CD10 positive T cells in angioimmunoblastic T-cell lymphoma. Leukemia 2006;20:296-303.

8 Lee SS, Rudiger T, Odenwald T, et al. Angioimmunoblastic $\mathrm{T}$ cell lymphoma is derived from mature $\mathrm{T}$ helper cells with varying expression and loss of detectable CD4. Int J Cancer 2003;103:12-20.

9 Dorfman DM, Brown JA, ShaHsafaei A, et al. Programmed death-1 (PD-1) is a marker of germinal centerassociated $\mathrm{T}$ cells and angio-immunoblastic T-cell lymphoma. Am J Surg Pathol 2006;30:802-810.

10 de Leval L, Rickman DS, Thielen C, et al. The gene expression profile of nodal peripheral T-cell lymphoma demonstrates a molecular link between angioimmunoblastic T-cell lymphoma (AITL) and follicular helper T (TFH) cells. Blood 2007;109:4952-4963.

11 Piccaluga PP, Agostinelli C, Califano A, et al. Gene expression analysis of angioimmunoblastic lymphoma indicates derivation from $\mathrm{T}$ follicular helper cells and vascular endothelial growth factor deregulation. Cancer Res 2007;67:10703-10710.

12 Grogg KL, Attygalle AD, Macon WR, et al. Expression of CXCL13, a chemokine highly upregulated in germinal center T-helper cells, distinguishes angioimmunoblastic T-cell lymphoma from peripheral T-cell lymphoma, unspecified. Mod Pathol 2006;19: 1101-1107. 
13 Dupuis J, Boye K, Martin N, et al. Expression of CXCL13 by neoplastic cells in angioimmunoblastic Tcell lymphoma (AITL): a new diagnostic marker providing evidence that AITL derives from follicular helper T cells. Am J Surg Pathol 2006;30:490-494.

14 Krenacs L, Schaerli P, Kis G, et al. Phenotype of neoplastic cells in angioimmunoblastic T-cell lymphoma is consistent with activated follicular B helper $\mathrm{T}$ cells. Blood 2006;108:1110-1111.

15 Roncador G, García Verdes-Montenegro JF, Tedoldi S, et al. Expression of two markers of germinal center $\mathrm{T}$ cells (SAP and PD-1) in angioimmunoblastic T-cell lymphoma. Haematologica 2007;92:1059-1066.

16 Rodriguez-Justo $\mathrm{M}$, Attygalle $\mathrm{AD}$, Munson $\mathrm{P}$, et al. Angioimmunoblastic T-cell lymphoma with hyperplastic germinal centres: a neoplasia with origin in the outer zone of the germinal centre? Clinicopathological and immunohistochemical study of 10 cases with follicular T-cell markers. Mod Pathol 2009;22:753-761.

17 Marafioti T, Paterson JC, Ballabio E, et al. The inducible T-cell co-stimulator molecule is expressed on subsets of $\mathrm{T}$ cells and is a new marker of lymphomas of $\mathrm{T}$ follicular helper cell-derivation. Haematologica 2010;95:432-439.

18 Serke S, van Lessen A, Hummel M, et al. Circulating CD4+ T lymphocytes with intracellular but no surface CD3 antigen in five of seven patients consecutively diagnosed with angioimmunoblastic T-cell lymphoma. Cytometry 2000;42:180-187.

19 Diaz-Alderete A, Menarguez J, Alvarez-Doval A, et al. Lymphocyte immunophenotype of circulating angioimmunoblastic T-cell lymphoma cells. Br J Haematol 2006;134:347-348.

20 Theodorou I, Bigorgne C, Delfau MH, et al. VJ rearrangements of the TCR locus in peripheral T-cell lymphomas: analysis by polymerase chain reaction and denaturing gradient gel electrophoresis. J Pathol 1996;178:303-310.

21 van Dongen JJ, Langerak AW, Bruggemann M, et al. Design and standardization of PCR primers and protocols for detection of clonal immunoglobulin and T-cell receptor gene recombinations in suspect lymphoproliferations: report of the BIOMED-2 Concerted Action BMH4-CT98-3936. Leukemia 2003;7: 2257-2317.

22 Rawstron AC, Villamor N, Ritgen M, et al. International standardized approach for flow cytometric residual disease monitoring in chronic lymphocytic leukaemia. Leukemia 2007;21:956-964.

23 San-Miguel JF, Vidriales MB, Orfão A. Immunological evaluation of minimal residual disease (MRD) in acute myeloid leukaemia (AML). Best Pract Res Clin Haematol 2002;15:105-118.

24 Schaerli P, Willimann K, Lang AB, et al. CXC chemokine receptor 5 expression defines follicular homing T cells with B cell helper function. J Exp Med 2000;192:1553-1562.

25 Breitfeld D, Ohl L, Kremmer E, et al. Follicular B helper $\mathrm{T}$ cells express CXC chemokine receptor 5, localize to B cell follicles, and support immunoglobulin production. J Exp Med 2000;192:1545-1552.

26 Lim HW, Kim CH. Loss of IL-7 receptor alpha on CD4+ $\mathrm{T}$ cells defines terminally differentiated B cell-helping effector $\mathrm{T}$ cells in a $\mathrm{B}$ cell-rich lymphoid tissue. J Immunol 2007;179:7448-7456.

27 Chtanova T, Tangye SG, Newton R, et al. T follicular helper cells express a distinctive transcriptional profile, reflecting their role as non-Th1/Th2 effector cells that provide help for B cells. J Immunol 2004; 173:68-78. 